INTERACTION: Jurnal Pendidikan Bahasa: Vol. 5, No.1: Mei 2018

ISSN: 2406-9558; E-ISSN: 2406-9566

\title{
Exploring Student's Ability in Applying Writing Mechanism in Recount Text
}

\author{
Onda Y. Purba \\ ondaypurba@gmail.com \\ MAN Model Sorong
}

\begin{abstract}
This study is carried out with the purposed that after gives the test by recount text. The students are hoped can be able to increase their ability in applying writing mechanism. This study is non-experimental research. Non-experimental is used as the mean in collecting the data. The population of this study was the students at the Third Grade of MAN Model Sorong in the years 2014/2015, by the number were 180 students. The sample of this study was the students of XII IPA I by the number were 23 students. The writer used only one test and nonexperimental design in this study. The result of study was presented into tables and had explained by percentage. In analysing data, the writer used table of category and score range in writing based on Sahidu. The result of this study showed that there were 11 students in excellent category $(47,8 \%), 7$ students in good category (30,4\%), 4 students in average category $(17.3 \%)$ and the last in poor category 1 student $(4,34 \%)$. The mean from 23 students, there are 11 students almost writing perfectly in using the 6 elements in punctuation and capital letters. The writer concluded that ability of the students in XII IPA I in MAN MODEL Sorong was used capital letters and punctuation good enough.
\end{abstract}

Key words: Punctuation,

\section{INTRODUCTION}

Writing is one example of comunnication. With writing skill students can tell about their opinion, idea, feeling, experience and many others on paper. People often forget to apply writing mechanism to their writing when composing emails or in short message. But students must know about mechanism in writing. In this case, the students make mistake or error in applying writing mecanism on recount text. The students make error, when they are want to write their experiences in the past but they not write with punctutation or applying writing mecanism clearly. That is the reason for the writer want to analysis the students' error in applying writing mecanism and the writer will involve all case in applying writing mecanism. 
INTERACTION: Jurnal Pendidikan Bahasa: Vol. 5, No.1: Mei 2018

ISSN: 2406-9558; E-ISSN: 2406-9566

\section{LITERATURE REVIEW}

\section{Previous of Study}

Dessy Wanarni, 2012 previously also investigate about mechanism in punctuation. On her researh "Ability in Using Punctuation on Description of Student in SMA 13 Tanggerang", she's examine student's ability in description essay. And her can find out the ability of student in using punctuation.

Ahmad Azhar (2013) did the research about "The Ability of Students in Using Punctuation On Writing Official letter of Students at Mts. Tajhis Diniyah Bengkalis". In this research Ahmad Azhar also investigate about punctuation. To detect about students ability in using punctuation, he gave a test to write official letters. This research is purpose to know about the ability of students in using punctuation.

After the earlier research above, the writer want to explain about this research. In this research, the writer investigate about punctuation too. The writer will do the research in MAN Model Sorong on Jln. Basuki Rahmat No. 40 Kota Sorong. And the writer chooses XII class as the sample. The writer using quantitative descriptive as the research design.

\section{METHOD}

\section{Design}

In research design, the writer wanted to explain this research into non-experimental because this research did not apply the treatment or without treatment. That was intended to explain or describe the students ability in using punctuation and capital letters, there was no treatment applied in this study.

\section{Analysis Data}

To know about the score of students ability, writer apply the table of category and the scores range in writing based on Sopia, 2006, p.23)

Table 1. Table of Category and Score Range in Writing based on Sopia

\begin{tabular}{|l|l|l|}
\hline No & Category & Score range \\
\hline 1 & Exelent & $85-100$ \\
\hline 2 & Good & $70-84$ \\
\hline 3 & Average & $56-69$ \\
\hline
\end{tabular}


INTERACTION: Jurnal Pendidikan Bahasa: Vol. 5, No.1: Mei 2018

ISSN: 2406-9558; E-ISSN: 2406-9566

\begin{tabular}{|l|l|l|}
\hline 4 & Poor & $50-55$ \\
\hline 5 & Very poor & $00-49$ \\
\hline
\end{tabular}

To find out the percentage of each category, the formula below is used:

$$
\begin{aligned}
& \text { Percentage }(\%)=\frac{\mathbf{N}}{\mathbf{n}} \quad \mathrm{X} \quad \mathbf{1 0 0 \%} \\
& \mathbf{n}=\text { number of students on each category } \\
& \mathbf{N}=\text { Number of samples }
\end{aligned}
$$

\section{RESULT AND DISCUSSION}

\section{Result}

Table 3. Table of category and the score range result of students

\begin{tabular}{|l|c|c|c|}
\hline No & Names & Category & Score Range \\
\hline 1 & A & Good & 70 \\
2 & B & Good & 75 \\
3 & C & Good & 84 \\
4 & D & Average & 65 \\
5 & E & Average & 60 \\
6 & F & Exelent & 85 \\
7 & G & Exelent & 85 \\
8 & H & Exelent & 90 \\
9 & I & Exelent & 85 \\
10 & J & Good & 70 \\
11 & K & Good & 70 \\
12 & L & Good & 70 \\
13 & M & Poor & 55 \\
14 & N & Exelent & 90 \\
15 & O & Average & 60 \\
16 & P & Exelent & 85 \\
17 & Q & Exelent & 85 \\
18 & R & Average & 65 \\
19 & S & Exelent & 85 \\
\hline
\end{tabular}




\begin{tabular}{|l|c|c|c|}
\hline 20 & $\mathrm{~T}$ & Good & 75 \\
21 & $\mathrm{U}$ & Exelent & 85 \\
22 & $\mathrm{~V}$ & Exelent & 90 \\
23 & $\mathrm{~W}$ & Exelent & 85 \\
& & & \\
\hline
\end{tabular}

To find out the percentage of each category, the writer indicated the result with the formula below :

\section{Excelent category}

In excelent category, students could achieve the score range of 85-100.

Tabel 3. Tabel score range in exelent category

\begin{tabular}{|l|c|c|}
\hline No & Names & Score Range \\
\hline $\mathbf{1}$ & E & 85 \\
\hline $\mathbf{2}$ & G & 85 \\
\hline $\mathbf{3}$ & H & 100 \\
\hline $\mathbf{4}$ & I & 85 \\
\hline $\mathbf{5}$ & N & 90 \\
\hline $\mathbf{6}$ & P & 85 \\
\hline $\mathbf{7}$ & Q & 85 \\
\hline $\mathbf{8}$ & U & 85 \\
\hline $\mathbf{9}$ & V & 90 \\
\hline $\mathbf{1 0}$ & W & 85 \\
\hline $\mathbf{1 1}$ & S & 100 \\
\hline
\end{tabular}

$$
11 \times 100 \%=47.8 \%
$$

In this category, there are 11 students had high value because the student in above almost writing perfectly in using the 6 elements in punctuation $\mathrm{n}$ capitalization. And percentage of exelent category was $47.8 \%$.

\section{Good category}

In good category, students could achieve the score range 70 - 84 .

Table 4. Table score range in good category

\begin{tabular}{|l|c|c|}
\hline No & Names & Score Range \\
\hline $\mathbf{1}$ & A & 70 \\
\hline $\mathbf{2}$ & B & 75 \\
\hline
\end{tabular}




\begin{tabular}{|l|l|l|}
\hline $\mathbf{3}$ & $\mathrm{C}$ & 84 \\
\hline $\mathbf{4}$ & $\mathrm{J}$ & 70 \\
\hline $\mathbf{5}$ & $\mathrm{K}$ & 70 \\
\hline $\mathbf{6}$ & $\mathrm{L}$ & 70 \\
\hline $\mathbf{7}$ & $\mathrm{T}$ & 75 \\
\hline
\end{tabular}

$$
7 \times 100 \%=30.4 \%
$$

In good category, there are 7 students who dicvored enough value in applying writing mechanism and the percentage in this category is $30,4 \%$.

\section{Average category}

In average category, students could achieve the score range $60-69$.

Table 5. Table score range in average category

\begin{tabular}{|c|c|c|}
\hline No & Names & Score Range \\
\hline $\mathbf{1}$ & $\mathrm{D}$ & 65 \\
\hline $\mathbf{2}$ & $\mathrm{E}$ & 60 \\
\hline $\mathbf{3}$ & $\mathrm{O}$ & 60 \\
\hline $\mathbf{4}$ & $\mathrm{R}$ & 65 \\
\hline
\end{tabular}

$$
\frac{4}{23} \times 100 \%=17.3 \%
$$

In average category, there are 4 students who discored enough value in applying writing mechanism and the percentage in this category was $17.3 \%$.

\section{Poor category}

In poor category, students had a low value in this study. The score range in poor category was $50-55$.

Table 6. Table score range in poor category

\begin{tabular}{|c|c|c|}
\hline No & Names & Score Range \\
\hline $\mathbf{1}$ & $\mathrm{M}$ & 55 \\
\hline
\end{tabular}

$1 \times 100 \%=4.34 \%$ 
In this category, there are only one students who made many error in her text. And the percentage is $4.34 \%$.

After the writer calculated the total error in each category above of error that student made in using punctuation and capitalization and the result:

Table 7. Table of total percentage

\begin{tabular}{|c|c|c|}
\hline Category & Total students & Percentage (\%) \\
\hline Excelent & 11 & $47.8 \%$ \\
Good & 7 & $30.4 \%$ \\
Average & 4 & $17.3 \%$ \\
Poor & 1 & $4.34 \%$ \\
Very Poor & - & \\
\hline Total & 23 & $99.84 \%$ \\
\hline
\end{tabular}

In table above explain about total percentage of all category in students ability in used punctuation and capitalization in recount text. In excelent category $47.8 \%$, good category $30,4 \%$, average category $17,3 \%$, poor category $4,34 \%$. And the total of percentage from each category was $99,84 \%$. From the result, the writer concluded that the student of XII IPA 1 in MAN MODEL SORONG classified clever because they were good in writing and know about using the 6 elements of punctuation and capitalization.

\section{Discussion of Result}

We can saw in table above explain about total percentage of all category in students ability in using punctuation and capitalization in recount text. In excelent category 47.8 any 11 students, good category $30.4 \%$ any 7 students, average category $17.3 \%$ any 4 , poor category $4.34 \%$ any 1 students. And the total of percentage from each category is $99.84 \%$.

The result of the students in used 6 elements of punctuation and capital letters, the writer calculated total error and the result is:

1) Fullstop (.)

Total students error in used fullstop in their sentences is 14 students from 23 students or $60.86 \%$

2) Comma (,)

Total students error in used fullstop in their sentences is 11 students from 23 students or $47.82 \%$

3) Colon (:) 
INTERACTION: Jurnal Pendidikan Bahasa: Vol. 5, No.1: Mei 2018

ISSN: 2406-9558; E-ISSN: 2406-9566

Total students error in used fullstop in their sentences is 9 students from 23 students or $39.13 \%$

4) Question (?)

Total students error in used fullstop in their sentences is 6 students from 23 students or $20.08 \%$

5) Exlamation (!)

Total students error in used fullstop in their sentences is 3 students from 23 students or $13.04 \%$

6) Quotation marks ( “...”) \& (“...)

Total students error in used fullstop in their sentences is 3 students from 23 students or $13.04 \%$

7) Capital Letters

Total students error in used fullstop in their sentences is 18 students from 23 students or $78.26 \%$

In this case, students often ignored in using the punctuation and capital letters. The teacher can examine students with gave the attractive topic in writing. More and more gave an exercise for students, so the teacher can improved their ability not only in applying writing mechanism, but can increase vocabulary too. That it can be the good solution for students and the teacher too in increase the students' ability.

\section{CONCLUSION}

From the result, the writer concluded that the student of XII IPA 1 in MAN MODEL SORONG as the sample classified into clever because the student's ability generally good enough in applying writing mechanism in recount text.

\section{REFERENCES}

Azhar, A. 2013. The Ability of Students in Using Punctuation in Writing Official Letter of The students at Mts. Tajhis Diniyah Bengkalis. Kabupaten Bengkalis.

Bratcher, Suzanne. (2004). Evaluating Children's Writing: a handbook of grading choices for classroom teachers.

New Jersey: Lawrence Erlbaum Associates, Inc.Brown, H. Douglas. (2000).Principles of Language Learning and Teaching.New York: Pearson Education Ltd. (2001).Teaching by Principles: an interactive approach to language pedagogy.Second Edition. New York: Pearson Education Ltd.

Dale, Helen. (1997). Co-Authoring in the Classroom: Creating an Environment forEffective Collaboration.Theory \& Practice Research into Practice. Illinois: Viewpoints.

Ferris,D. R. (2003). Response to Student Writing: Implications for Second Language Students. New Jersey: Lawrence Erlbaum Associates Publishers. 
INTERACTION: Jurnal Pendidikan Bahasa: Vol. 5, No.1: Mei 2018

ISSN: 2406-9558; E-ISSN: 2406-9566

Graham, S. and Perin, Dolores. (2007). Writing Next: Effective Strategies to Improve Writing of Adolescents in Middle and High School. New York: Alliance.

Harmer, J. (2004). How to Teach Writing. Edinburg: Pearson Education Ltd.

Harmer, J. (2007). The Practice of English Language Teaching. Edinburg: Pearson Education Ltd.

Johnson, Andrew. P. (2008). Teaching Reading and Writing: a guidebook for tutoring and remediating students. Maryland: Rowman and Little field Education.

Knapp, P., Watkins, M. (2005). Genre, Text, Grammar: Technologies for teaching and assessing writing. Sydney: University of New South Wales Press.

Murray,Rowena and Moore,Sarah. (2006). The Handbook of Academic Writing: A Fresh Approach. New York: McGraw Hill Education

Nation, I. S. P. (2009). Teaching ESL/ EFL Reading and Writing.New York and London: Routledge Publisher.

93Pulverness, A., Spratt, M., and Williams, M. (2005). Teaching Knowledge Test Course. New York: Cambridge University Press.

Richard, J. C. and Rodgers, T. S. (2001). Approaches and Methods in Language Teaching. Cambridge: Cambridge University Press.

Rumiaek, L. A.and Zemach, D. E. (2005). Academic Writing: fronm paragraph to essay. Oxford:Macmillan Publisher.

Storch, Neomy. (2005). Collaborative Writing: Product, Process, and Students' reflections. Journal of Second Language Writing, No. 14, pp. 153-173

Wanarni, D. 2012. Skripsi, The Ability in Using Punctuation on Description of Student in SMA 13 Tanggerang. Jakarta.

Weigle, Sara Cushing. 2002. Assessing Writing. Cambridge: Cambridge University Press.

Urquhart,Vicki and McIver,Monette. (2005). Teaching writing in the content areas. MA: Association for Supervision and Curriculum Development 